\title{
On the relation between architectural considerations and heating energy performance of Turkish residential buildings in Izmir
}

\author{
Tuğçe Kazanasmaz ${ }^{\mathrm{a}, *}$, Ilknur Erlalelitepe Uygun ${ }^{\mathrm{a}}$, Gülden Gökçen Akkurt ${ }^{\mathrm{b}}$, \\ Cihan Turhan ${ }^{c}$, Kenan Evren Ekmen ${ }^{c}$ \\ a Dept. Architecture, Izmir Institute of Technology, Gulbahce Kampus, Urla, Izmir 35430, Turkey \\ ${ }^{\mathrm{b}}$ Mechanical Engineering, Izmir Institute of Technology, Gulbahce Kampus, Urla, Izmir 35430, Turkey \\ c Energy Engineering Program, Izmir Institute of Technology, Gulbahce Kampus, Urla, Izmir 35430, Turkey
}

\section{A R T I C L E I N F O}

\section{Article history:}

Received 15 October 2012

Received in revised form

19 December 2013

Accepted 23 December 2013

\section{Keywords:}

Residential buildings

Energy performance

Architectural configuration

Efficient design

Legislation

İzmir

\begin{abstract}
A B S T R A C T
By considering the energy efficiency legislations among the European Union, Turkey is responsible to provide regulations to comply for the latest European Energy Performance of Buildings Directive 2010/31/EC. New legislation in Turkey requires information about the evaluation of energy performance of existing buildings. This study aimed to determine energy performance of residential buildings in Izmir, regarding significant relationships between their performance and architectural configuration through statistical analysis. The focus was on the heating energy consumption due to Energy Efficiency Law (2007) and Building Energy Performance Regulation (2008), and Standard Assessment Method for Energy Performance of Dwellings (KEP-SDM). This energy performance assessment method was based on Turkish standard TS 825, and European standard EN ISO 13790. It is known that architectural configuration of buildings and design norms have impact on energy performance of buildings. However, emphasis was given on significant values of architectural considerations through certain area-based ratios. The levels of these ratios were matched with the levels of energy consumption. By this, the consideration was to take early-precautions against high energy consumptions in the early design stage and to enhance legislation by adding recommendations of concrete architectural values. These would assist to predict the level of energy performance in the early design phase. Findings would provide feedback information on the residential building stock in İzmir, Turkey.
\end{abstract}

(c) 2014 Elsevier B.V. All rights reserved.

\section{Introduction}

The construction of residential buildings in Turkey is rife with proposals that lay claim in improving efficiency due to sheltering needs of increasing population and providing a qualified habitat [1-3]. In addition, construction has become an expensive sector relatively among others. Due to the fuel crisis in 1970s, energy efficiency has been a critical issue to reduce energy cost and to ensure sustainability of energy throughout the world, and in Turkey as well. As the residential heating is the main source for energy and resource consumption in Turkey, residential buildings have gained utmost concern nowadays to reduce energy and resource consumption. Utilizing dwellings offering comfortable interior spaces,

\footnotetext{
* Corresponding author. Tel.: +90 232 7507063; fax: +90 2327507012.

E-mail addresses: tugcekazanasmaz@iyte.edu.tr, ztugcek@gmail.com (T. Kazanasmaz), ilknurerlalelitepe@iyte.edu.tr (İ.E. Uygun), guldengokcen@iyte.edu.tr (G.G. Akkurt), cihanturhan@iyte.edu.tr (C. Turhan), kenanekmen@iyte.edu.tr (K.E. Ekmen).
}

it would also be possible to reduce harmful gases released into the environment $[4,5]$. According to construction permits given in $2000-2008$, almost $80 \%$ of buildings are residential, and $80 \%$ of the total energy consumption of buildings are for the heating purposes. That is why the energy efficient methods in the construction sector are based on insulation applications to avoid heat loss [6]. According to the breakdown of energy use in buildings in Turkey, almost $80 \%$ of energy consumption derived from conventional fuel use, as seen in Fig. 1; thus 75\% of energy is used for heating and cooling [7,8].

Regarding energy statistics, the rate of heating energy consumption caused by residential buildings is almost $30 \%$ of the total energy consumption in Turkey. Considering the heating energy consumption of other functional types of buildings, and the insufficient fuels used in heating systems, the contribution of this sector to the whole air pollution becomes enormous. According to those statistics, the real heating energy consumption in residential buildings ranges between 100 and $200 \mathrm{kWh} / \mathrm{m}^{2}$ (the average is obtained as $175 \mathrm{kWh} / \mathrm{m}^{2}$ ) in Turkey. However, in European countries, this value is $100 \mathrm{kWh} / \mathrm{m}^{2}$, including energy use of heating, cooling and 


\begin{tabular}{|c|c|}
\hline \multicolumn{2}{|c|}{ Nomenclature } \\
\hline$A$ & area $\left(\mathrm{m}^{2}\right)$ \\
\hline cal. & calculated \\
\hline cri. & critical \\
\hline$C$ & specific heat capacity $(\mathrm{mJ} / \mathrm{kg} \mathrm{K})$ \\
\hline DD & degree days $\left({ }^{\circ} \mathrm{C}\right.$ day $)$ \\
\hline df & degrees of freedom \\
\hline E & east \\
\hline EP & energy performance \\
\hline$F$ & factor $(1)$ \\
\hline$g_{\mathrm{n}}$ & total solar energy transmittance factor $(-)$ \\
\hline H.S. & heating system \\
\hline & solar irradiance $\left(\mathrm{w} / \mathrm{m}^{2}\right)$ \\
\hline$Q$ & quantity of heat (MJ) \\
\hline MS & mean squares \\
\hline$n$ & number \\
\hline $\mathrm{N}$ & north \\
\hline$V$ & volume $\left(\mathrm{m}^{3}\right)$ \\
\hline$U$ & thermal transmittance $\left(\mathrm{w} / \mathrm{m}^{2} \mathrm{~K}\right)$ \\
\hline$P$ & probability \\
\hline S & south \\
\hline GGE & greenhouse gases emission \\
\hline SS & sum of squares \\
\hline Stat & statistic \\
\hline W & west \\
\hline \multicolumn{2}{|c|}{ Greek symbols } \\
\hline$\alpha$ & level of significance \\
\hline$\rho$ & density $\left(\mathrm{kg} / \mathrm{m}^{3}\right)$ \\
\hline$\theta$ & temperature $\left({ }^{\circ} \mathrm{C}\right)$ \\
\hline \multicolumn{2}{|c|}{ Subscripts } \\
\hline a & air \\
\hline Adj & adjusted \\
\hline alt & altitude \\
\hline $\mathrm{C}$ & ceiling \\
\hline $\mathrm{d}$ & dwelling \\
\hline $\mathrm{F}$ & frame \\
\hline f & floor \\
\hline gn & gain \\
\hline $\mathrm{L}$ & lighting \\
\hline ls & losses \\
\hline $\mathrm{m}$ & month \\
\hline $\mathrm{mn}$ & mean \\
\hline $\operatorname{sh}$ & shading \\
\hline $\mathrm{T}$ & total \\
\hline $\operatorname{tr}$ & transmission \\
\hline $\mathrm{v}$ & ventilation \\
\hline $\mathrm{w}$ & wall \\
\hline wi & window \\
\hline$\perp$ & perpendicular \\
\hline
\end{tabular}

ventilation $[9,10]$. Another study which subjected to two Greek cities of similar climate as in İzmir, focused on heating energy demand of residential buildings. Results indicated that mean real heating energy consumption was $101.03 \mathrm{kWh} / \mathrm{m}^{2}$, simulated result was $112.78 \mathrm{kWh} / \mathrm{m}^{2}$ [11]. Recently, the existing studies in European countries are based on the reducing the real energy consumption of residential buildings below $50 \mathrm{kWh} / \mathrm{m}^{2}$ [10]. New buildings constructed according to the recent regulations in Turkey consume energy two times higher than the ones built in EU countries. Insulation regulations in different countries offer such values as $23 \mathrm{kWh} / \mathrm{m}^{2}$ in Denmark, $34 \mathrm{kWh} / \mathrm{m}^{2}$ in Netherlands, $35 \mathrm{kWh} / \mathrm{m}^{2}$

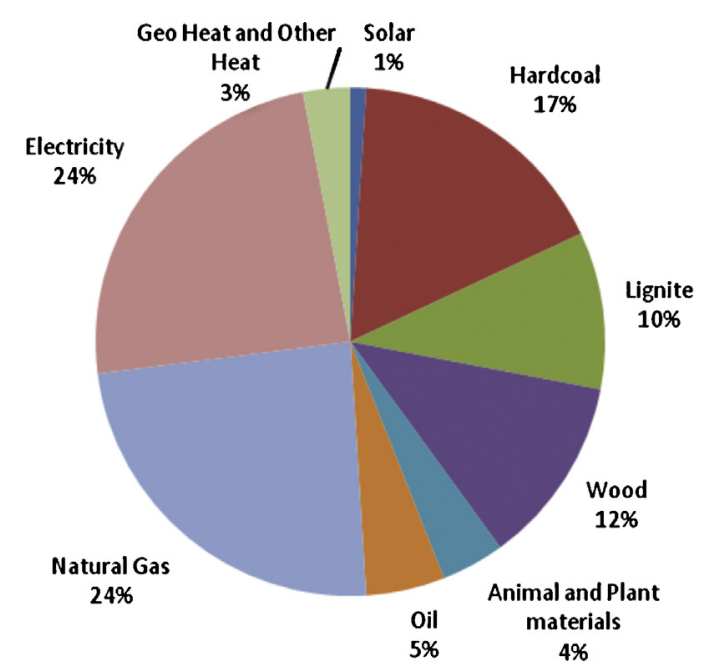

Fig. 1. The breakdown of energy sources in buildings in Turkey [8].

in United Kingdom [9]. These values were extensively lower than the proposed values of Turkish standards. Considering these above issues, it has been worth to study energy consumption of residential buildings in Turkey.

From the beginning of the 1990s, the Member States in Europe dealt with the legal regulations about energy consumption in order to reduce carbon dioxide emissions, according to Kyoto Protocol. Turkey is now responsible to provide regulations to comply for the latest European Energy Performance of Buildings Directive 2010/31/EC [6]. In particular, the thermal insulation requirements for buildings-TS825 and Heat Insulation Regulation (2000) were legally adopted in 2000: the latter is the complementary regulation of the former which offers the calculation method for the energy demand for heating in buildings [12,13]. Turkey complied with the rules by Directive 2010/31/EC, through Energy Efficiency Law (2007) and Building Energy Performance Regulation (2008). As regards to these regulations, the following actions were proposed: the evaluation for the energy consumption of buildings, the classification of buildings and determination of minimum energy performance requirements of existing buildings for their renovation [14,15]. "Standard Assessment Method for Energy Performance of Buildings" has been developed by The Ministry of Public Works and was introduced in January 2011. It drafted energy certificate and compared the energy performance of a building with ascertained energy limits. Legislation requires information about the evaluation of energy performance of new buildings and existing buildings which will be renovated. Thus, this study has become a preparation for this issue. It was understood that regulations in Turkey were, in general, based on heating energy demand of buildings. Also that, it was similar to other countries of similar regional climate, like Greece, as reviewed from literature $[11,16] .61 \%$ of total energy for residential buildings is consumed for space heating and only $2 \%$ for refrigeration [17]. These considerations directed us to focus on studying the heating energy consumption in Izmir.

It is also known that architectural configuration of buildings and design norms have direct impact on energy performance of buildings. However, in this study, it is aimed to offer certain significant values of architectural indicators to be used in the architectural design process. By this, it is thought that early-precautions against high energy consumptions would be taken in the design stage.

Related studies were conducted and various rating systems in EU countries were announced to determine energy rating of existing buildings [1,5,18-22]. Theodoridou et al., studied energy consumption of residential building stock of two Greek cities. They classified existing dwellings and applied statistical analysis 
between the heating energy consumption and the variables such as the construction year, the buildings' typology, the glazing type and the income $[11,16]$. In addition, governments' standard assessment procedures for energy rating of dwellings were published such as SAP2005 in UK [23]. Other studies offered methods including meteorological and sociological influences on thermal load and energy estimations [24]; or impact of occupant behavior on energy consumption in dwellings [25].

In addition, several methods have been proposed and used to estimate effects of architectural design factors on energy demand. They involved such variables as thermo-physical characteristics of the exterior walls, building orientation and geometry, building location. Simulation programs have been commonly used as in the researches and they showed significant impact of these variables on heating energy consumption and energy efficiency [26-36]. Several studies pointed out the very slight effect of window dimension on heating energy demand but showed the distinct impact on cooling energy demand [28-30]. Another study concluded that the significant impact of occupant characteristics and behavior on energy use was $4.2 \%$, while the effect of building characteristics was significantly leading with the rate of $42 \%$. It showed the interaction effect between the dwelling type and insulation; i.e. high thickness of insulation significantly resulted to higher energy consumption than flats with low thickness of insulation [25].

In view of these resent research and ongoing knowledge, this study was conducted for residential buildings in İmir, which is the third most populated city of Turkey. The aim is to determine the heating energy performance of residential buildings in İzmir; and to define relations between their energy performance and their architectural configuration by statistical analysis. Utilizing these, it would be possible to propose certain boundary values for architectural indicators. This would provide architects and engineers opportunity to encounter such problems in the design stage and give chance to propose precautions before the construction process and before the buildings are in use.

Energy performance of building case studies were determined by using a calculation method named as The Standard Assessment Method for Energy Performance of Dwellings (KEP-SDM). It is thought that this study conducted for İmir, would be a representative one which might be adapted for other cities.

\section{Existing residential buildings in İzmir}

\subsection{Physical facilities and sampling}

İzmir is situated in the western of Turkey (latitude $38^{\circ} 25^{\prime} \mathrm{N}$, longitude $27^{\circ} 08^{\prime} \mathrm{E}$ ), by the Aegean Sea. İzmir has a typical Mediterranean climate which is characterized as temperate-humid. The average minimum temperatures during winter vary between 6 and $8{ }^{\circ} \mathrm{C}$. Monthly mean temperatures, however, during summer (May-October) are almost $25^{\circ} \mathrm{C}$ or higher. The annual mean global radiation is $4.1 \mathrm{kWh} / \mathrm{m}^{2}$ day. The prediction of the annual degreedays is $1361\left(19^{\circ} \mathrm{C}\right)$ for heating and $360\left(23^{\circ} \mathrm{C}\right)$ for cooling. Solar altitude angle is $28.04^{\circ}$ and azimuth $272.76^{\circ}$ at noon for winter solstice; while the former is $68.40^{\circ}$ and the latter is $321.65^{\circ}$ for summer solstice [37].

According to Building Construction Statistics by Turkish Statistical Institute, the number of multi-story residential buildings is $40 \%$ of the whole residential buildings constructed from 1960s to 2008, in Izmir [38]. This rate tends to increase because of increasing population and lack of construction area. Thus, subject buildings in this study were defined to be 5-11 story residential buildings. The municipalities of Konak, Karabağlar and Balçova have the highest rate of multi-story buildings of around 50\% in İzmir. Therefore, they are considered as typical for sampling with respect to buildings' construction year, zoning status, orientation and floor counts. Municipality of Konak is situated at the city centre, a representative area of high population, which is defined as a dense urban region with high construction rate since 1970s. Municipality of Karabağlar was separated from the Municipality of Konak and displayed a variation of buildings constructed after 1970s, particularly in 1990s. Majority of buildings in Konak and Karabağlar are attached with one or two sides. However, Municipality of Balçova is a typical example of a rather newly developed region, with the majority of buildings having detached zoning status and constructed in 2000s.

Thus, a total of 148 buildings were selected from three municipalities due to variation in zoning status and high construction rate. Among these, 50 out of 148 were in Konak, the other 50 were in Balçova and the rest in Karabağlar. Architectural and mechanical production drawings were obtained from archives of related municipalities.

\subsection{Data compilation and nature of data}

The data collection method was based on the analysis of architectural projects and obtaining/calculating dimensional data written on drawings of residential buildings in order to understand the architectural configuration and heating characteristics. So, the study material consisted of architectural and mechanical drawings obtained from three municipalities mentioned above. An archive research was conducted to analyze project documents, construction permits and technical reports about the architectural and mechanical characteristics of each building. Relevant numerical and verbal data were recorded on separate sheets of each selected building. Data obtained from the construction permits included the address, construction year and designer's professional status. However, data obtained from architectural drawings included floor counts in a building, zoning status, width and height of the building, total floor area, net-usable floor area, total floor area of common spaces, total volume, total area of façade, window area, wall area, while the heating system type, heating load and $U$-values of materials were obtained from mechanical drawings. An example of a data record sheet is shown in Fig. 2. Accordingly, the composition of buildings' thermal envelope due to their construction year is given in Table 1, while the ratio of glazing area to external wall area ranged from 0.1 to 0.6 , normally distributed on each orientation. There are two groups of compositions (before and after 2000) regarding the application year of Heat Insulation Regulation as mentioned in Table 1. Among these groups, the roof, floor and window compositions are the same for all buildings investigated according to their architectural drawings. It was observed that similar construction techniques and materials without heat insulation have been used before 2000. However, heat insulation was involved in the construction by applying new techniques after 2000 . There are a few architectural drawings which does not involve any information about their building envelope. So, it was assumed that the same materials were used in these buildings as well. Utilizing such typical compositions of the building envelope for each building, it is possible to notice the impact of architectural (dimensional) configuration indicators on heating energy performance. However, the admittance, thermal lag and solar absorption are not considered since the method used in this study, KEP-SDM, is a monthly static method which does not involve these parameters in the calculation procedure, unlike dynamic methods [39]. The operation of the heating system during weekdays and weekends is continuous for all buildings in order to be able to compare their energy consumption. The buildings are defined as high rise buildings with concrete walls. Considering this, KEP-SDM calculates the infiltration rate according to the EN 13465 [40]. 


\begin{tabular}{|c|c|c|c|c|c|c|c|c|c|}
\hline \multicolumn{4}{|c|}{ GENERAL DESCRIPTION } & \multicolumn{6}{|c|}{$\begin{array}{c}\text { DATA OBTAINED FROM } \\
\text { MECHANICAL DRAWINGS }\end{array}$} \\
\hline \multicolumn{4}{|c|}{ KONAK 01} & \multicolumn{4}{|c|}{ U values $\left(\mathrm{W} / \mathrm{m}^{2} \mathrm{~K}\right)$} & \multirow{2}{*}{\multicolumn{2}{|c|}{1.64}} \\
\hline \multicolumn{2}{|l|}{ City } & \multicolumn{2}{|c|}{ İzmir } & \multicolumn{4}{|c|}{$\begin{array}{r}\text { wall } \\
\end{array}$} & & \\
\hline \multicolumn{2}{|c|}{ Municipality } & \multicolumn{2}{|c|}{ Konak } & \multicolumn{4}{|r|}{ roof } & \multicolumn{2}{|r|}{0.53} \\
\hline \multicolumn{2}{|c|}{ Adress (district/island/parcel) } & \multicolumn{2}{|c|}{ Göztepe } & \multicolumn{4}{|r|}{ floor } & \multicolumn{2}{|r|}{1.07} \\
\hline \multicolumn{2}{|c|}{ Construction year } & \multicolumn{2}{|c|}{1983} & \multicolumn{4}{|c|}{ window } & \multicolumn{2}{|r|}{5.1} \\
\hline \multicolumn{2}{|c|}{ Floor counts } & \multicolumn{2}{|c|}{5} & \multicolumn{4}{|c|}{ Heating system types } & \multicolumn{2}{|c|}{ autonomous } \\
\hline \multicolumn{2}{|c|}{ Number of residential units } & \multicolumn{2}{|l|}{5} & \multicolumn{4}{|c|}{ Fuel type } & \multicolumn{2}{|c|}{ coal-fired stove } \\
\hline \multicolumn{2}{|c|}{ Professional status } & \multicolumn{2}{|c|}{ Architect (B.Arch) } & \multicolumn{4}{|c|}{ Heating load $\left(\mathrm{kWh} / \mathrm{m}^{3}\right)$} & & 863.71 \\
\hline & DATA OB & 3TAINED FR & OM ARC & HITEC & CTURA & L DRA & AWINC & & \\
\hline & Zoning Stat & & & & Attach & ed/Inte & ermedia & & \\
\hline & Orientation & & & & & $\mathrm{N} / \mathrm{S}$ & & & \\
\hline & Width and 1 & height of the $b$ & uilding ( & & & $6.55 / 1$ & 2.5 & & \\
\hline & Total floor & $\operatorname{area}\left(\mathrm{m}^{2}\right)$ & & & & 81.8 & & & \\
\hline & Net usable & floor area $\left(\mathrm{m}^{2}\right)$ & & & & 321.7 & & & \\
\hline & Total floor & area of comm & on spaces & $\left(\mathrm{m}^{2}\right)$ & & 37.3 & & & \\
\hline & Total volun & $\mathrm{ne}\left(\mathrm{m}^{3}\right)$ & & & & 868.6 & & & \\
\hline & Total extern & nal surface are & $a\left(m^{2}\right)$ & & & 213.6 & & & \\
\hline DATA OF & Total volume & Floor height & Wal & area $(1$ & & Wind & low are & $\left(\mathrm{m}^{2}\right)$ & Total net \\
\hline $\begin{array}{l}\text { RESIDENTIAL } \\
\text { UNITS }\end{array}$ & $\left(\mathrm{m}^{3}\right)$ & $\left(\mathrm{m}^{3}\right)$ & $\mathrm{N}$ & $\mathrm{S}$ & total & $\mathrm{N}$ & $\mathrm{S}$ & total & $\begin{array}{l}\text { usable floor } \\
\text { area }\left(\mathrm{m}^{2}\right)\end{array}$ \\
\hline Z01 & 171.99 & 2.7 & 18.78 & 22.8 & 41.58 & 3 & 2.76 & 5.76 & 63.67 \\
\hline 101 & 174.17 & 2.7 & 14.5 & 19.78 & 34.28 & 4.28 & 3.02 & 7.3 & 64.51 \\
\hline 201 & 174.17 & 2.7 & 14.5 & 19.78 & 34.28 & 4.28 & 3.02 & 7.3 & 64.51 \\
\hline 301 & 174.17 & 2.7 & 14.5 & 19.78 & 34.28 & 4.28 & 3.02 & 7.3 & 64.51 \\
\hline 401 & 174.17 & 2.7 & 14.5 & 19.78 & 34.28 & 4.28 & 3.02 & 7.3 & 64.51 \\
\hline
\end{tabular}

Fig. 2. An example of a data record sheet.

\subsection{Architectural configuration indicators}

Relevant attributes of the architectural configuration for these buildings are basically zoning status, orientation, floor counts, area/volume ratio (calculated with floor slab), construction year together with other related factors such as designer's professional status and the heating system. In addition to data cited in previous section, relevant areas of architectural configuration calculated from drawings were the following: net-usable floor area (inclusive of all internal areas left out from footprint area of all structural elements); external surface area (calculated from external perimeter and the floor to ceiling height of residential building); net-usable common floor area (the exclusive of all residential flats from netusable floor area); window area (area where high amount of heat would be gained/lost); external wall area and external dimension(width and length).

Architectural configuration indicators were, then, used to conduct the assessment for the occurrence of significant relations between energy performances and architectural configuration of buildings. These ratios derived from above areas are described below;

Ratio of external surface area to net usable floor area (R1): This is an indicator that reflects the form of building by its volume in zoning status. So it is highly related in exterior surface design and in cost efficiency of energy consumption by concerning surfaces.

Ratio of window area to external surface area (R2): This was viewed as the indicator for the equilibrium of solid-void, describing effects of void surfaces to hold minimum heat load.

Table 1

The composition of building envelope, before and after Heat Insulation Regulation (2000).

\begin{tabular}{|c|c|c|c|c|}
\hline & Externall wall & Roof & Floor & Window \\
\hline Before 2000 & $\begin{array}{l}0.05 \text { m cement mortar } \\
0.19 \text { m vertically perforated brick } \\
0.03 \text { m lime cement mortar }\end{array}$ & $\begin{array}{l}0.05 \mathrm{~m} \text { cement mortar screed } \\
0.05 \mathrm{~m} \text { insulation } \\
0.1 \mathrm{~m} \text { concrete } \\
0.02 \mathrm{~m} \text { lime mortar }\end{array}$ & $\begin{array}{l}0.02 \mathrm{~m} \text { granite } \\
0.02 \mathrm{~m} \text { cement mortar screed } \\
0.1 \mathrm{~m} \text { concrete } \\
0.1 \mathrm{~m} \text { crushed stone } \\
0.1 \mathrm{~m} \text { cohesive soil }\end{array}$ & $\begin{array}{l}\text { Wood frame } \\
\text { Single glass }\end{array}$ \\
\hline $\begin{array}{l}U \text { value } \\
\text { After } 2000\end{array}$ & $\begin{array}{l}1.64 \mathrm{~W} / \mathrm{m}^{2} \mathrm{~K} \\
0.02 \mathrm{~m} \text { lime cement mortar } \\
0.085 \mathrm{~m} \text { horizontally perforated brick } \\
0.04 \mathrm{~m} \text { PU rigid foam } \\
0.135 \mathrm{~m} \text { horizontally perforated brick } \\
0.03 \mathrm{~m} \text { lime cement mortar }\end{array}$ & $\begin{array}{l}0.53 \mathrm{~W} / \mathrm{m}^{2} \mathrm{~K} \\
0.05 \mathrm{~m} \text { cement mortar } \\
0.05 \mathrm{~m} \text { insulation } \\
0.05 \mathrm{~m} \text { insulation } \\
0.1 \mathrm{~m} \text { concrete } \\
0.02 \mathrm{~m} \text { lime mortar }\end{array}$ & $\begin{array}{l}1.07 \mathrm{~W} / \mathrm{m}^{2} \mathrm{~K} \\
0.02 \mathrm{~m} \text { granite } \\
0.03 \mathrm{~m} \text { cement mortar screed } \\
0.15 \mathrm{~m} \text { concrete } \\
0.15 \mathrm{~m} \text { coal slag }\end{array}$ & $\begin{array}{l}5.1 \mathrm{~W} / \mathrm{m}^{2} \mathrm{~K} \\
\text { PVC frame } \\
\text { Double glass }\end{array}$ \\
\hline$U$ value & $0.53 \mathrm{~W} / \mathrm{m}^{2} \mathrm{~K}$ & $0.32 \mathrm{~W} / \mathrm{m}^{2} \mathrm{~K}$ & $0.52 \mathrm{~W} / \mathrm{m}^{2} \mathrm{~K}$ & $2.1 \mathrm{~W} / \mathrm{m}^{2} \mathrm{~K}$ \\
\hline
\end{tabular}


Ratio of width to length (R3): This indicator determines maximum utility spaces and building surfaces in the suggested zoning plan.

Ratio of external wall area to net-usable area (R4): This ratio was used to define design efficiency indicator related flexibility, utility and cost efficiency of designed spaces. It is the one of the general design principle, creating minimum wall area and minimum fragment plan scheme.

Ratio of net-usable common floor area to net-usable floor area (R5): Minimum common spaces have great potential on useful spaces to make them usable and generative. It is related to management cost of before and after construction.

Ratio of heating load to external surface area (R6): This ratio is an indicator of the efficiency power of the external surface area in controlling the heating load of the building. It is assumed that a higher value for this ratio would result in design deficiency, since high amount of energy will be consumed.

Ratio of heating load to net-usable floor area (R7): This ratio shows how sensitive a designer is in order to balance all effective factors in determining the heating load of the building. It determines to what extent this heating load is reflected to the building users.

Ratio of lighting load to net-usable floor area (R8): This ratio is an indicator of the efficiency power of the net-usable floor area in determining the lighting load of the building.

These ratios are classified due to their frequency distributions and their subdivisions were defined explicitly depending on the nature of the data before statistical analysis. They define level of indicators as mentioned in Table 4. For example, R1 have four levels of indicators, namely, very low $(0.022<\mathrm{R} 1<0.288)$, low $(0.289<\mathrm{R} 1<0.554)$, medium $(0.555<\mathrm{R} 1<0.820)$, high $(0.830<\mathrm{R} 1)$. The distribution of energy consumption among these indicators was analyzed by the analysis of variance as mentioned in Section $3.2[41]$.

\section{Data analysis}

\subsection{Method of KEP-SDM}

According to the latest energy regulation in Turkey, new buildings and the ones under major renovation are urged to obtain an "Energy Certificate" by utilizing a calculation procedure. The Standard Assessment Method for Energy Performance of Dwellings (KEP-SDM) was developed as a part of this requirement including heating, domestic hot water production and lighting energy consumptions and $\mathrm{CO}_{2}$ emissions of dwellings only by the Chamber of Mechanical Engineers, Izmir Institute of Technology and Istanbul Technical University in 2008. The method is referred to TS 825 $[12,13]$ which provides a framework for the calculation of heating energy demand in buildings and European standard EN ISO 13790 (2008) [39]. The testing and validation of this tool is according to BESTEST (Building Energy Simulation Test) which is an internationally recognized procedure $[42,43]$.

According to EN ISO 13790 (2008), there are three classifications of energy performance evaluation methods: seasonal or monthly static method, simple hourly dynamic method (simple dynamic) and detailed hourly dynamic method (full dynamic). KEP-SDM is a monthly method including degree-day correction. The calculation is based on the energy balance considering a range of factors which contribute to energy efficiency, as mentioned below:

- Materials used for construction of the dwelling.

- Thermal insulation of the building fabric.

- Ventilation characteristics of the dwelling and ventilation equipment.

- Efficiency and control of the heating system(s).

- Solar gains through openings of the dwelling.
Table 2

The range of energy and $\mathrm{CO}_{2}$ classes for İzmir [15].

\begin{tabular}{llll}
\hline Energy class & $\mathrm{kWh} / \mathrm{m}^{2}$ year & $\mathrm{CO}_{2}$ class & $\mathrm{kg} \mathrm{CO} / \mathrm{m}^{2}$ year \\
\hline $\mathrm{A}$ & $\mathrm{EP}<72$ & $\mathrm{~A}$ & $\mathrm{GGE}<12$ \\
$\mathrm{~B}$ & $72<\mathrm{EP}<144$ & $\mathrm{~B}$ & $12<\mathrm{GGE}<24$ \\
$\mathrm{C}$ & $144<\mathrm{EP}<180$ & $\mathrm{C}$ & $24<\mathrm{GGE}<30$ \\
$\mathrm{D}$ & $180<\mathrm{EP}<216$ & $\mathrm{D}$ & $30<\mathrm{GGE}<36$ \\
$\mathrm{E}$ & $216<\mathrm{EP}<252$ & $\mathrm{E}$ & $36<\mathrm{GGE}<42$ \\
$\mathrm{~F}$ & $252<\mathrm{EP}<315$ & $\mathrm{~F}$ & $42<\mathrm{GGE}<52.5$ \\
$\mathrm{G}$ & $315<\mathrm{EP}$ & $\mathrm{G}$ & $52.5<\mathrm{GGE}$ \\
\hline
\end{tabular}

- The fuel used to provide space and water heating, ventilation and lighting.

- Renewable energy technologies.

The calculation is independent of factors related to the individual characteristics of the household occupying the dwelling, as mentioned below:

- Household size and composition.

- Ownership and efficiency of particular domestic electrical appliances.

- Individual heating patterns and temperatures.

KEP-SDM defines the dwelling as a single-zone but internal temperature is differentiated according to the living area and the rest. The calculation takes into account thermal bridges in the building unlike thermal mass of the building. Weather data is available in weather database obtained from National Meteorological Institution for each city.

The outputs of the method are annual energy consumption per unit floor area $\left(\mathrm{kWh} / \mathrm{m}^{2}\right.$ year $)$ and annual $\mathrm{CO}_{2}$ emissions per unit floor area $\left(\mathrm{kg} \mathrm{CO}_{2} / \mathrm{m}^{2}\right.$ year $)$. The energy performance of building case studies in three municipalities were calculated and each building's energy class (Class A to $\mathrm{G}$ ) and $\mathrm{CO}_{2}$ class (Class A to $\mathrm{G}$ ) were determined together with the annual energy consumption per unit floor area $\left(\mathrm{kWh} / \mathrm{m}^{2}\right.$ year) and annual $\mathrm{CO}_{2}$ emissions per unit floor area $\left(\mathrm{kg} \mathrm{CO}_{2} / \mathrm{m}^{2}\right.$ year) with their boundary values as given in Table 2.

In detail, the principal calculation steps of this calculation methodology are (Fig. 3):

1. definition of the building dimensions (number of floors, floor area, floor height), description of heating system (operation type, heating type, fuel type, type of water heating)and boundary conditions (type of building, inside temperature) for the calculation of energy needs,

2. calculation of the heat loss by ventilation (1) with number of air changes and overall air leakage value for the dwellings,

$Q_{\mathrm{V}}=\rho_{\mathrm{a}} C_{\mathrm{p}, \mathrm{a}}\left(n V_{\mathrm{d}}\right)$

3. calculation of the heat transfer by transmission (2) including $u$-values (specific for opaque surfaces, glazed surfaces) and thermal bridges,

$\left.Q_{\mathrm{tr}}=U_{\mathrm{W}} A_{\mathrm{W}}+U_{\mathrm{wi}} A_{\mathrm{wi}}+U_{\mathrm{c}} A_{\mathrm{c}}+F_{\mathrm{adj}, \mathrm{f}} U_{\mathrm{f}} A_{\mathrm{f}}\right)$

4. calculation of the energy need for water heating (it is calculated annually according to the existence of solar water heating system and floor area. The calculation based on EN 15316-3-1,2 and 3) [44-46] and the internal heat gains (they are calculated by considering the amount of heat released from building occupants and equipment, lighting fixtures and mechanical devices. The calculation based on EN 13790) [39], 


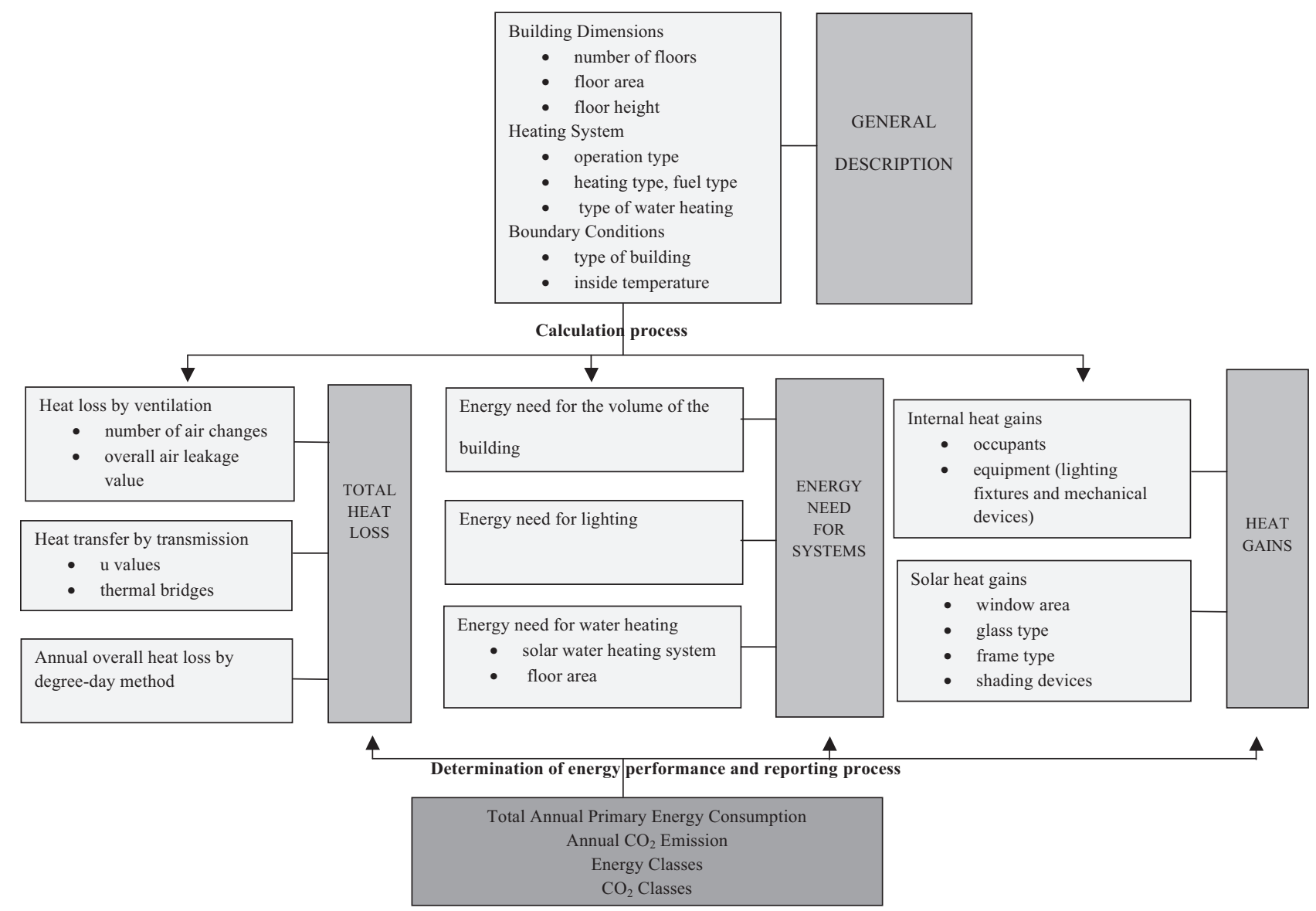

Fig. 3. Flow chart of the calculation procedure according to KEP-SDM.

5. calculation of the solar heat gains ( 3 ) by employing such parameters as window area, glass type, frame type and shading devices (4) and (5), (the calculation is based on EN 13790) [39],

$$
\begin{aligned}
& Q_{n, m}=\sum_{i=1}^{i=n} I_{\text {sol }, m} A_{\mathrm{g}, m} g_{m} F_{\mathrm{sh}} \\
& g_{n, m}=F_{\text {adjg } \perp} \\
& F_{\text {sh }}=F_{\text {alt }} \times F F \times F_{\text {adj,sh }}\left(F_{\text {adj }}=0.9\right)
\end{aligned}
$$

6. determination of average internal temperature by deciding on the operation hours of the heating.

7. calculation of the annual overall heat loss (6) by degree-day method,

$$
\theta_{\mathrm{DD}}=\theta_{m n}-\frac{Q_{g n}}{Q T, l s}
$$

8. calculation of the energy need ( 7 ) for the volume of the building,

$$
Q_{\mathrm{V}}=0.024 \times \mathrm{DD} \times Q_{\mathrm{T}, \mathrm{ls}}(\mathrm{kWh} / \text { year })
$$

9. calculation of the lighting energy need (8),

$Q_{\mathrm{L}}=E_{\mathrm{B}} \times C_{1} \times C_{2}$

( $E_{\mathrm{B}}$ is the primary energy consumption value per square meter for low energy lighting bulb; $C_{1}$ is the adjustment factor; $C_{2}$ is the adjustment factor due to daylight effect) [23],

10. determination of total annual primary energy consumption by calculating energy consumption of heating, water heating and lighting systems; determination of annual $\mathrm{CO}_{2}$ emission similarly,

11. reporting the energy and $\mathrm{CO}_{2}$ classes according to these values.

\subsection{Statistical analysis}

The statistical analysis was carried out by using the SPSS and MS Excel software program. The data elaboration included ANOVA, $t$-Test and regression analysis. The MS Excel software program was also used in the preparation of tables displaying results. Eight factors were analyzed single factor ANOVA at a 5\% level of significance $(\alpha=0.05)$. These were the difference between the energy consumption and professional status; zoning status; orientation; floor counts in a building; construction year; heating system; area/volume ratio; architectural configuration indicators (R1, R2, R3, R4, R5, R8).

These analyses were repeated for significant differences between these factors and $\mathrm{CO}_{2}$ emission. The relation between architectural configuration indicators-R6 (Ratio of heating load to external surface area), R7 (Ratio of heating load to net-usable floor area) and energy consumption were analyzed by $t$-Test: TwoSample Assuming Unequal Variances. Similar analyses using the same variables were applied for $\mathrm{CO}_{2}$ emissions. A final regression (prediction) model was applied by utilizing architectural configuration indicators to determine their total impact on energy consumption.

According to statistical analysis, the key year is 2000, thus the thermal insulation requirements for buildings-TS825 and Heat Insulation Regulation were legally adopted in 2000. Most of the 


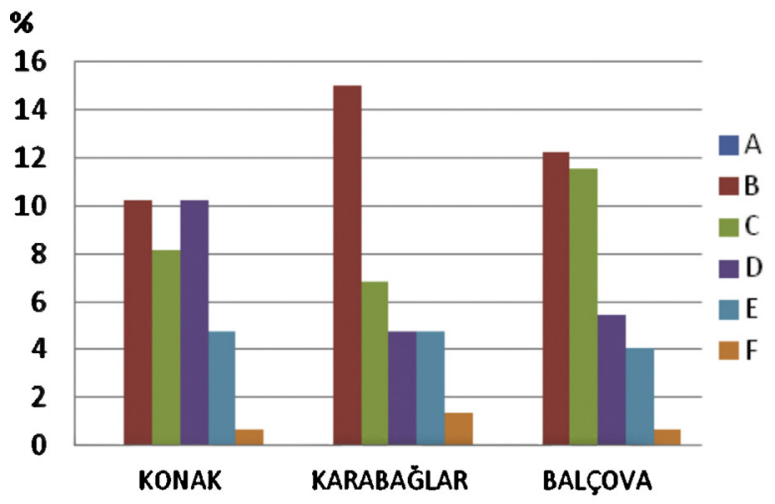

(a)

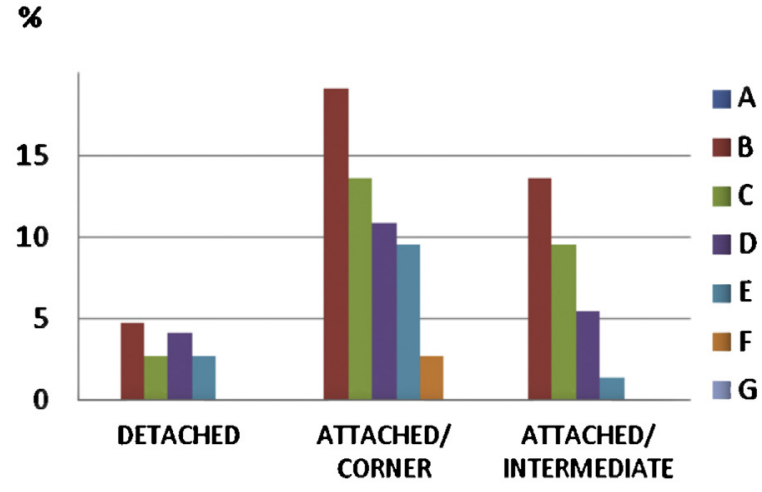

(c)

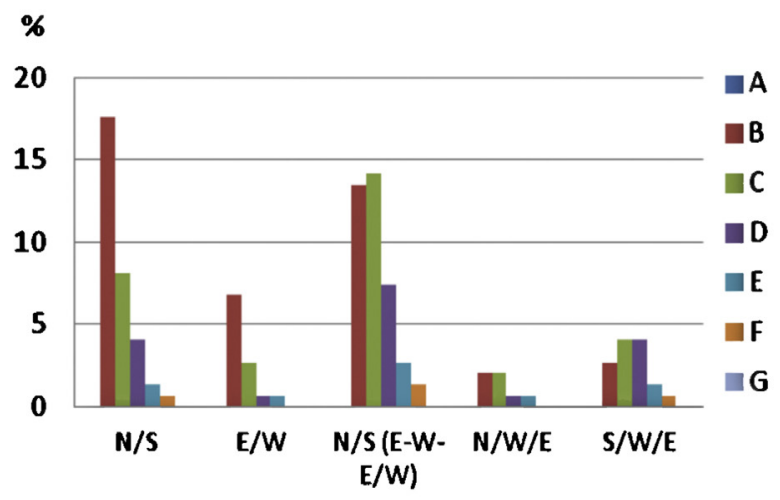

(e)

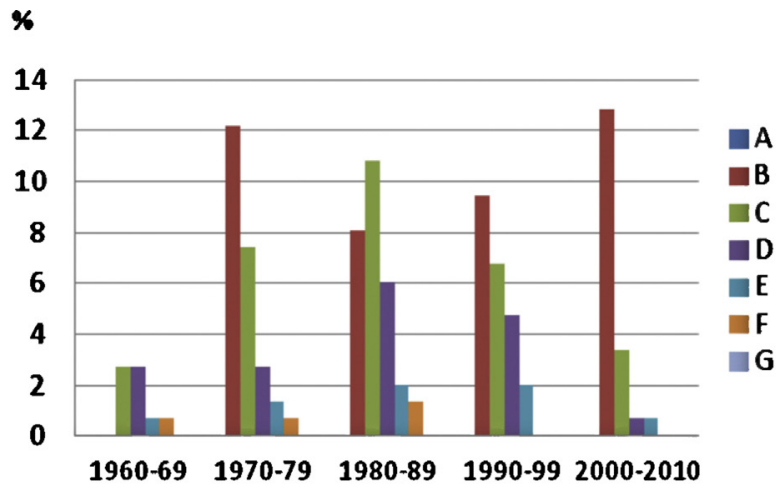

(b)

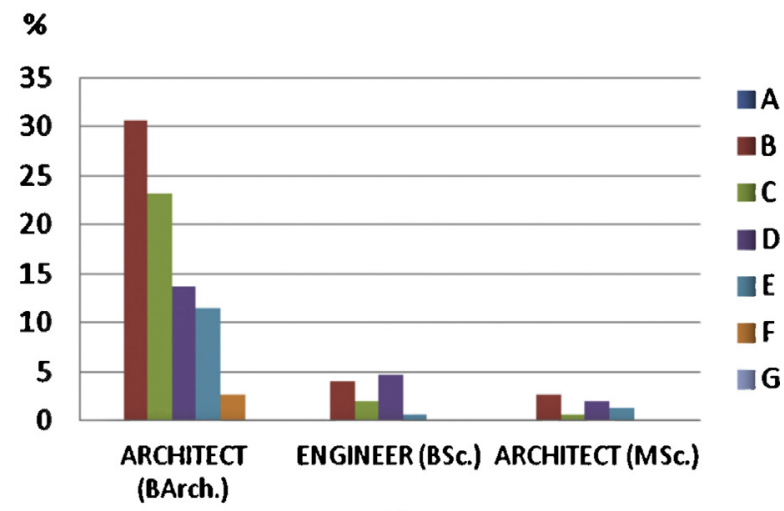

(d)

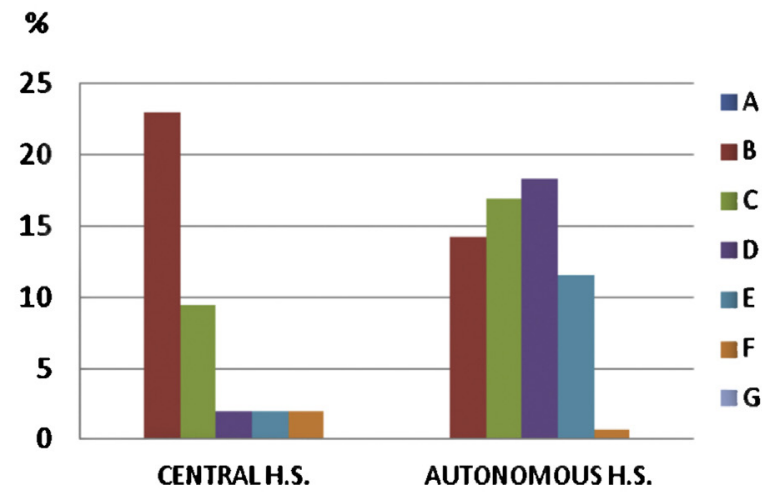

(f)

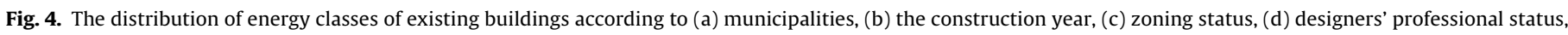
(e) orientation, (f) heating system.

buildings constructed before 2000 in İzmir are uninsulated. The relation between insulation and energy consumption was analyzed by $t$-Test. This was repeated according to $\mathrm{CO}_{2}$ emissions, $\mathrm{CO}_{2}$ classes and energy classes.

\section{Results}

\subsection{General results}

The results regarding the main characteristics of the residential buildings are presented in Fig. 4. The finding, which showed the majority of the buildings being in Energy Class B and C, was in accordance with the Building Energy Performance Regulation (2008). The highest rate of buildings being in Energy Class D, E and $\mathrm{F}$ was in Konak. The buildings of Konak displayed relatively higher energy consumptions than the ones of Karabağlar and Balçova. The reason might be that their construction years were between 1960 and 1999. That period was typical, since it was before the implementation of the TS825 and Heat Insulation Regulation (in 2000), and the constructions included old building materials applied with old construction techniques. However, most of the buildings constructed after 2000, in Karabağlar and Balçova, were in Energy Class $\mathrm{B}$, since this period was to be the characteristic for the growth in construction sector due to technological improvements and contemporary building materials (such as well insulated buildings with less air infiltration).

A very critical issue, regarding energy performance, was about whether the building was detached or not. So, the zoning status of the case buildings were defined as attached/corner (attached to a building on one side and situated at the corner), attached/intermediate (attached to a building on two opposite 
sides) and detached (not attached to a building) with a rate of $55.6 \%$, $29.9 \%$ and $14.5 \%$ respectively. This is an ordinary feature of buildings in Turkish city centers, which are extremely densely built. Among these groups, a total rate of buildings in Energy Class B was 37\%, and in Energy Class C was 25.8\%. Another critical aspect was whether the building faced to south, north or east/west. Since calculations for energy performance included the solar gain attained from window area and coefficients to calculate solar gain changes according to orientation. The majority of buildings have south-north facades with $31.7 \%$, while $14 \%$ of the total buildings have south-north-west facades, $11 \%$ of these face south-north-east, $12 \%$ face south-northwest-east and the other $12 \%$ face south-east-west. The fact that these values being close to each other shows the unsystematic urban planning with the inconsideration of orientation to reach a certain energy efficiency. This is an expected finding since there is no legislation in association with this issue in Turkey. By the categorization of buildings according to the design professionals, the majority of them were designed by architects, except a few which were constructed earlier.

It is a known fact that the type of heating system dominantly determines the operating efficiency of heating systems and the fuel type affects the $\mathrm{CO}_{2}$ emission of a building relatively $[6,23,47]$. The findings, here, supported this information. The minority of buildings involves oil-fired central heating system $\left(153.2 \mathrm{kwh} / \mathrm{m}^{2}\right)$, however almost $61 \%$ of them have autonomous heating systems (as coal-fired stove; $157.2 \mathrm{kwh} / \mathrm{m}^{2}$ ). The result, which showed $30 \%$ of the buildings being in Energy Class D and $\mathrm{E}$ had autonomous heating systems. On the other hand, $22 \%$ of the buildings which had oil-fired central heating system were in Class $\mathrm{B}$. Regarding $\mathrm{CO}_{2}$ emission, most of the buildings which were $57 \%$ of total buildings using autonomous heating system (as coal-fired stove) were in $\mathrm{CO}_{2}$ Class $\mathrm{G}$. It should be considered that this information relied on mechanical production projects, and users' preferences were eliminated; also to simplify types of heating systems provided opportunity to compare architectural variables efficiently for this study. Also, the role of occupancy, the energy efficiency awareness of users or economic based measures might result in various heating types when buildings are in use. Thus, the use of common autonomous systems, i.e. air conditioning systems, would lead to poor energy performance and extensive $\mathrm{CO}_{2}$ emissions as in Fig. 5 .

\subsection{Statistical results}

\subsubsection{Energy consumption according to relevant attributes of the architectural configuration}

The results of single-factor ANOVA according to seven variables are presented below with a tabular form in Table 3. The findings of $t$-Test according to insulation and heating system are also summarized under the same table. First, it was concluded that professional status did not vary significantly according to energy consumption, on the contrary, zoning status varied significantly according to energy consumption. The mean value of energy consumptions

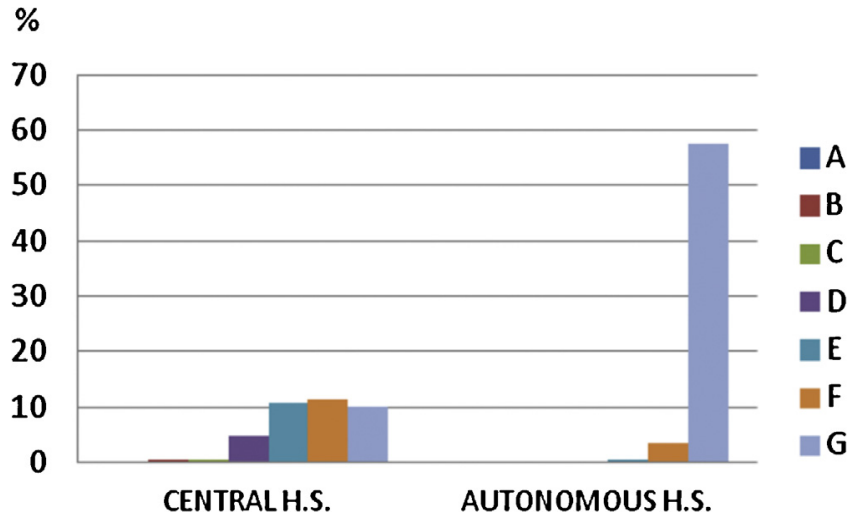

Fig. 5. The distribution of $\mathrm{CO}_{2}$ classes of existing buildings according to heating system.

for attached/intermediate buildings was $138.71 \mathrm{kWh} / \mathrm{m}^{2}$ year, whereas it was $161.26 \mathrm{kWh} / \mathrm{m}^{2}$ year for attached/corner buildings. Detached buildings had almost higher mean energy consumption of $170.66 \mathrm{kWh} / \mathrm{m}^{2}$ year. It is apparent that the increase in the exterior surface area causes energy losses accordingly.

Regarding the orientation, its significant impact on the energy consumption, as supposed from previous studies [3,31,32,34], should be explained in relation to the buildings' zoning status and the amount of exterior surfaces. Since buildings which were attached/intermediate displayed the best energy performance are located in north/south and east/west direction, with a mean energy consumption of $146.50 \mathrm{kWh} / \mathrm{m}^{2}$ year and $148.86 \mathrm{kWh} / \mathrm{m}^{2}$ year respectively. As regards the floor counts in a building, there seemed to be no significant association with the energy consumption; however, the intermediate floors had better energy performance than the ground and the top floors. As the arithmetic mean of energy consumption values of all floors determine the building's total performance, it became clear that the higher the building, the lower the energy consumption; i.e. the 5-6 story buildings had approximately a mean energy consumption of $177 \mathrm{kWh} / \mathrm{m}^{2}$ year, while $7-9$ story buildings had approximately $158 \mathrm{kWh} / \mathrm{m}^{2}$ year.

The energy consumption was dependent of $A / V$ ratio, as expected $[2,3,23,48]$. The buildings whose $A / V$ ratios were between 0.37 and 0.41 had a mean energy consumption of $149.8 \mathrm{kWh} / \mathrm{m}^{2}$, whereas the ones with lower ratios, such as $0.33-0.37$, resulted to higher mean energy consumption of $182.04 \mathrm{kWh} / \mathrm{m}^{2}$. The reason might be that the construction period of the buildings whose $A / V$ ratios were between 0.37 and 0.41 can include recent years, when buildings with high quality and energy efficient building materials of high $u$-values have been mostly built. Or, the impact of zoning status might be so powerful that the energy consumption of the tall/or large buildings whose zoning status are detached or attached/corner may be lower than the others whose zoning status are attached/intermediate.

Table 3

Findings from the analysis of variance according to architectural attributes.

\begin{tabular}{|c|c|c|c|c|c|}
\hline & $F$ cal. & F cri. & $P$-value & $H_{0}: \tau_{\mathrm{i}}=0$ & Relation \\
\hline Zoning status & 6.42571 & 3.05849 & 0.00212 & Rejected & Significantly dependent \\
\hline Professional status & 0.043975 & 3.058486 & 0.956991 & Accepted & Significantly independent \\
\hline Orientation & 3.758751 & 2.44988 & 0.006517 & Rejected & Significantly dependent \\
\hline Area/volume ratio & 9.455892 & 3.072429 & 0.000154 & Rejected & Significantly dependent \\
\hline Floor counts in a building & 1.714127 & 2.667443 & 0.166733 & Accepted & Significantly independent \\
\hline \multirow[t]{2}{*}{ Construction year } & 7.545159 & 2.434947 & $1.52 \mathrm{E}-05$ & Rejected & Significantly dependent \\
\hline & $t$ Stat & $t$ Critical two-tail & $(P(T<=t)$ two-tail $)$ & $H_{0}: \tau_{\mathrm{i}}=0$ & Relation \\
\hline Insulation & 4.506535 & 2.015368 & $4.82 \mathrm{E}-05$ & Rejected & Significantly dependent \\
\hline Heating system & -0.745449269 & 1.98373095 & 0.457731475 & Accepted & Significantly independent \\
\hline
\end{tabular}




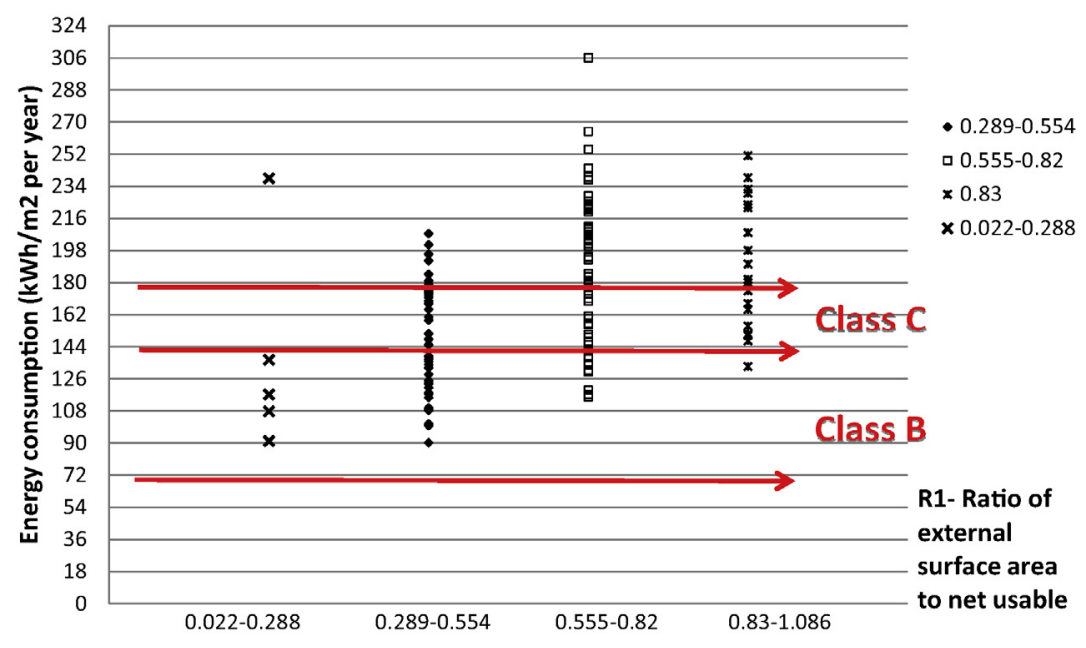

Fig. 6. Distribution of energy consumption according to R1.

Findings depicted the energy consumption of residential buildings were dependent on their construction year. There was the categorization of buildings regarding those constructed before 1970, during 1971-1980, 1981-1990, 1991-2000, and after 2000. In relation, the minimum mean energy consumption, which was $124.30 \mathrm{kWh} / \mathrm{m}^{2}$, was attained for the last ten-year-period. The reason seemed to be the use of insulation. Similar findings about insulation obtained from $t$-Test supported this conclusion. According to this, the mean values of energy consumption was $161.54 \mathrm{kWh} / \mathrm{m}^{2}$ for the buildings constructed before 2000 . However, this was $128.50 \mathrm{kWh} / \mathrm{m}^{2}$ for the ones built in $2000 \mathrm{~s}$. The period of 1970-1980 exhibited the second best energy performance of dwellings among five periods. A reasonable cause may be based on the form of the Municipality of Konak with the attached/intermediate buildings in such a densely populated region. In addition, the majority of these buildings are under the influence of south orientation. In general, this underlines the fact that such buildings are attached to each other to form a row-shape. Conversely, the mean values of energy consumption for the rest periods was $183.04 \mathrm{kWh} / \mathrm{m}^{2}$ for buildings built in $1960-1970 \mathrm{~s}$, $165.49 \mathrm{kWh} / \mathrm{m}^{2}$ in between 1980 and 1990 , and $165.31 \mathrm{kWh} / \mathrm{m}^{2}$ in between 1990 and 2000s. It was also concluded that heating system types did not affect the energy performance significantly due to their little impact on heating system efficiency.

One final and noteworthy finding here was that none of the case buildings were in Energy Class A and none of them benefited from renewable energy resources. This reminds us a question whether the use of such energy sources might upgrade these buildings' energy class from Class B to Class A or not.

\subsubsection{Relation between the energy consumption and the architectural configuration indicators}

If the mean values of energy consumption for each indicator were considered, several findings might be achieved. First, it becomes clear that the energy consumption increase as the values of R1, R4, R5, R7 and R8 increase. The dwellings whose ratio of external surface area to net usable area was between 0.289 and 0.554 referred to Class B and C. Almost $75 \%$ of these dwellings were in Class B. They attain a low mean energy consumption of $135.27 \mathrm{kWh} / \mathrm{m}^{2}$, whereas the average was $184.53 \mathrm{kWh} / \mathrm{m}^{2}$ for the dwellings with higher external surface area ratio (Fig. 6). Second, the values of R2 and R6 have impact on the energy consumption of buildings, albeit in the opposite direction. Findings about R2 underline the fact that minor changes in window area may result in the improvement of the energy behavior of the building. The majority of dwellings whose window area per external surface area was between 0.37 and 0.60 referred to Class B and C. Almost 74\% of these dwellings were in Class C. As this ratio was declining constantly, the mean energy consumption was rising, fortunately not to the expected scale. This may be due to the impact of orientation. Solar gain was under the control of both window area and the orientation. Third, it might not be, on the other hand, concluded that the increase in values of $\mathrm{R} 3$ result in any decrease/or increase of the energy performance.

High energy performance was mostly found in dwellings whose external wall area per net floor area values were lower than 0.604. Further investigations should be done before generalization this threshold to determine buildings' energy performance, in the design stage. However, it displays an indicative value that may be specific within these sample dwellings.

Results of the ANOVA and $t$-Test concerning the relation between the energy consumption and the architectural configuration indicators indicate that energy consumption was dependent of ratio of external surface area to net usable floor area (R1), ratio of window area to external surface area (R2), ratio of external wall area to net-usable area (R4), ratio of heating load to external surface area (R6), ratio of lighting load to net-usable floor area (R8); but independent of other indicators above. Considering that the ratio of external surface area to net usable floor area represents the form of the building by its volume in a specific zoning status, this was further evidence that the external wall area to net-usable area indicates how efficiently the building is designed. Studies [28-30] define the window area as an energy efficient design component. Window area influenced heating loads very slightly in those. In this study, the findings supported this situation similarly. In addition, window indicator, here, is not only the source of solar gain but also the determinant of the solid-void to balance heat load. The significant association between lighting and heating loads on energy performance was an expected finding [6,23]. One interesting point, here, is the independence of heating load per net usable area, which may be caused by the governing power of external surfaces to produce heat losses. Table 4 displays the impact of configuration indicators on the energy consumption of buildings. It summarizes the findings mentioned above by focusing on the levels of indicators and their condition of association to the energy consumption and $\mathrm{CO}_{2}$ emissions. Regarding dependent indicators, for example, a residential building, whose external surface area to net usable floor area is higher than 0.555 would display low energy performance. Specifically, if an architectural drawing of an example residential building is prepared in the early design phase; architectural 
Table 4

Impact of configuration indicators on the energy consumption of buildings.

\begin{tabular}{|c|c|c|c|c|}
\hline & Levels of indicators & & $\begin{array}{l}\text { According to energy consumption } \\
\text { Association }\end{array}$ & $\begin{array}{l}\text { According to } \mathrm{CO}_{2} \text { emission } \\
\text { Association }\end{array}$ \\
\hline $\mathrm{R} 1$ & $0.022-0.288$ & Very low & $\begin{array}{l}\text { - Higher levels of } \mathrm{R} 1 \text { result in lower energy and } \mathrm{CO}_{2} \\
\text { performance, relatively. }\end{array}$ & \\
\hline \multirow[t]{4}{*}{$\begin{array}{l}\text { Ratio of external surface area to net } \\
\text { usable floor area }\end{array}$} & $0.289-0.554$ & Low & $\begin{array}{l}\text { - The dwellings whose R1 was between } 0.289 \text { and } \\
0.554 \text { referred to Class B and C, significantly. }\end{array}$ & \\
\hline & $0.555-0.820$ & Medium & & \\
\hline & $0.830-\ldots$ & High & & \\
\hline & & & Association & Association \\
\hline $\mathrm{R} 2$ & $0.104-0.237$ & Low & $\begin{array}{l}\text { - Higher levels of } \mathrm{R} 2 \text { result in higher energy and } \mathrm{CO}_{2} \\
\text { performance, relatively. }\end{array}$ & \\
\hline \multirow[t]{2}{*}{$\begin{array}{l}\text { Ratio of window area to external } \\
\text { surface area }\end{array}$} & $0.238-0.360$ & Medium & $\begin{array}{l}\text { - The majority of dwellings whose } \mathrm{R} 2 \text { was between } \\
0.37 \text { and } 0.6 \text { referred to Class B and C, significantly. }\end{array}$ & \\
\hline & $0.370-0.600$ & High & & \\
\hline Datio f uidth to lonath & $0.212-0.408$ & Very low & $\begin{array}{l}\text { No association } \\
\text { - Higher/lower levels of } \mathrm{R} 3 \text { may not result in } \\
\text { lower/higher energy and } \mathrm{CO}_{2} \text { performance, relatively. }\end{array}$ & No association \\
\hline \multirow[t]{3}{*}{ Ratio of width to length } & $0.409-0.604$ & Low & & \\
\hline & $0.605-0.800$ & Medium & & \\
\hline & $0.800-\ldots$ & High & & \\
\hline R4 & $0.014-0.320$ & Very low & $\begin{array}{l}\text { Association } \\
\text { - Higher levels of R4 result in lower energy and } \mathrm{CO}_{2} \\
\text { performance, relatively. }\end{array}$ & Association \\
\hline \multirow[t]{3}{*}{$\begin{array}{l}\text { Ratio of external wall area to } \\
\text { net-usable area }\end{array}$} & $0.330-0.630$ & Low & $\begin{array}{l}\text { - High energy performance was mostly found in } \\
\text { dwellings whose R4 were lower than } 0.604 \text {. }\end{array}$ & \\
\hline & $0.640-0.940$ & Medium & & \\
\hline & $0.950-\ldots$ & High & & \\
\hline & & & No association & Association \\
\hline R5 & $0.004-0.045$ & Very low & $\begin{array}{l}\text { - Higher/lower levels of R5 may not result in } \\
\text { lower/higher energy performance, relatively. }\end{array}$ & \\
\hline \multirow[t]{4}{*}{$\begin{array}{l}\text { Ratio of net-usable common floor } \\
\text { area to net-usable floor area }\end{array}$} & $0.046-0.086$ & Low & $\begin{array}{l}\text { - Higher levels of } \mathrm{R} 5 \text { result in lower } \mathrm{CO}_{2} \text { performance, } \\
\text { relatively. }\end{array}$ & \\
\hline & $0.087-0.127$ & Medium & & \\
\hline & $0.128-\ldots$ & High & & \\
\hline & & & Association & Association \\
\hline R6 & $5.760-198.53$ & Low & $\begin{array}{l}\text { - Higher levels of } \mathrm{R} 6 \text { result in higher energy and } \mathrm{CO}_{2} \\
\text { performance, relatively. }\end{array}$ & \\
\hline $\begin{array}{l}\text { Ratio of heating load to external } \\
\text { surface area }\end{array}$ & $198.540-391.31$ & High & $\begin{array}{l}\text { - Most of the dwellings whose R6 was higher than } \\
198.53 \text { referred to Classes B and C, significantly. }\end{array}$ & \\
\hline 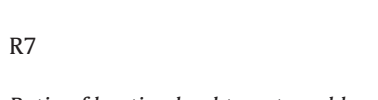 & $5.040-69.500$ & Low & $\begin{array}{l}\text { No association } \\
\text { - Higher/lower levels of } \mathrm{R} 7 \text { may not result in } \\
\text { lower/higher energy and } \mathrm{CO}_{2} \text { performance, relatively. }\end{array}$ & No association \\
\hline \multirow[t]{2}{*}{$\begin{array}{l}\text { Ratio of heating load to net-usable } \\
\text { floor area }\end{array}$} & $69.600-133.960$ & High & & \\
\hline & & & Association & Association \\
\hline R8 & $0.140-47.159$ & Low & $\begin{array}{l}\text { - Higher levels of R8 result in lower energy and } \mathrm{CO}_{2} \\
\text { performance, relatively. }\end{array}$ & \\
\hline \multirow{3}{*}{$\begin{array}{l}\text { Ratio of lighting load to net-usable } \\
\quad \text { floor area }\end{array}$} & $47.160-94.150$ & Medium & & \\
\hline & $94.150-141.150$ & High & & \\
\hline & & & Association & Association \\
\hline \multirow[t]{4}{*}{$A / V$} & $0.330-0.373$ & Low & $\begin{array}{l}\text { - Higher levels of } A / V \text { result in lower energy and } \mathrm{CO}_{2} \\
\text { performance, relatively. }\end{array}$ & \\
\hline & $0.374-0.416$ & Medium & $\begin{array}{l}\text { - The buildings whose } A / V \text { ratios were between } 0.37 \\
\text { and } 0.41 \mathrm{had} \text { a mean energy consumption of } \\
149.8 \mathrm{kWh} / \mathrm{m}^{2} \text { which referred to Class } C \text {. }\end{array}$ & \\
\hline & $0.417-\ldots$ & High & & \\
\hline & & & Association & Association \\
\hline \multirow[t]{4}{*}{ Orientation } & North/south & Very low & $\begin{array}{l}\text { - Higher levels of orientation result in lower energy } \\
\text { and } \mathrm{CO}_{2} \text { performance, relatively. }\end{array}$ & \\
\hline & East/west & Low & $\begin{array}{l}\text { - Buildings located in north/south and east/west } \\
\text { direction, with a mean energy consumption of } \\
146.50 \mathrm{kWh} / \mathrm{m}^{2} \text { year and } 148.86 \mathrm{kWh} / \mathrm{m}^{2} \text { year } \\
\text { respectively. These referred to Classes B and C. }\end{array}$ & \\
\hline & $\begin{array}{l}\text { North/east/west } \\
\text { (North/south/west, } \\
\text { north/south/east, } \\
\text { north/south/west/east) }\end{array}$ & $\begin{array}{l}\text { Medium } \\
\text { High }\end{array}$ & & \\
\hline & South/west/east & Very Low & & \\
\hline
\end{tabular}




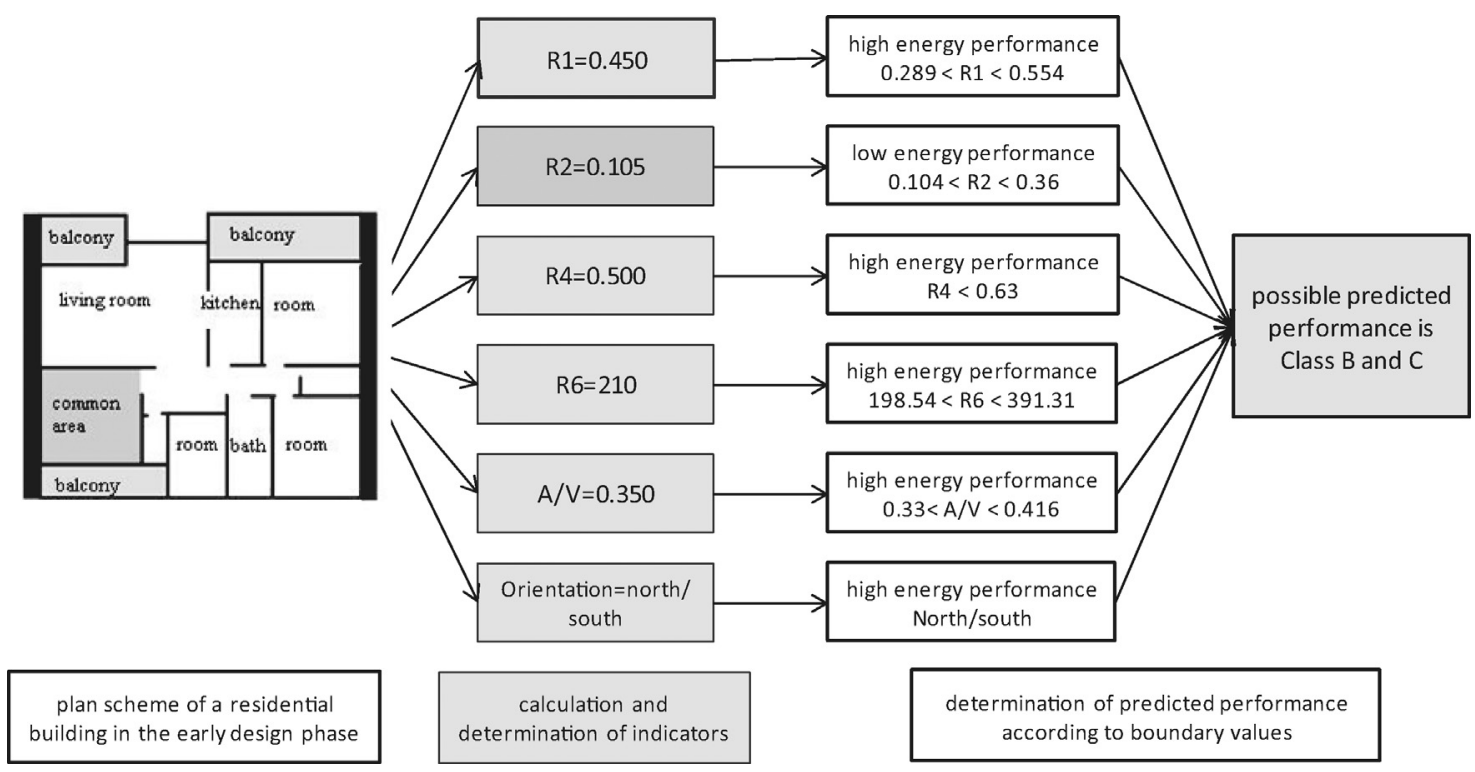

Fig. 7. Determination of predicted performance about an example building.

indicators may be calculated from this drawing as stated in Fig. 7. After that, the calculated value may be checked whether it is within the proposed boundary range or not. So, it may be suggested whether the energy performance of this building is low or high.

Finally, a regression model was constructed to predict the energy consumption by introducing the architectural configuration indicators into the standard regression analysis. According to the model, $47 \%\left(R^{2}=0.47\right)$ of the variability in the energy consumption is accounted for by the architectural indicators. According to the confidence level $(p<0.05)$, there obtained the significant relation between the predictors.

\subsubsection{Results for $\mathrm{CO}_{2}$ emissions}

The similar results were obtained from analyses of $\mathrm{CO}_{2}$ emissions except one, that is, the difference between $\mathrm{CO}_{2}$ emissions and floor counts. This is due to the fact that $\mathrm{CO}_{2}$ emission is the outcome of fuel consumption in terms of energy performance; so, higher the energy consumption, higher the $\mathrm{CO}_{2}$ emission. However, it was concluded that floors varied significantly according to $\mathrm{CO}_{2}$ emission, although the energy consumption was independent of floor counts. Accordingly $\mathrm{CO}_{2}$ emission, the majority of buildings was in $\mathrm{CO}_{2}$ Class $\mathrm{G}$. This finding confirms that most of the buildings of this study cause environmental pollution enormously. The reason may be using coal in autonomous heating systems and fuel-oil in central heating system. The electrical energy (air conditioning system) is also widely used in İzmir. All three types of fuel mentioned above damage the environment. The usage of natural gas should be encouraged.

\section{Concluding remarks}

This study included analysis of residential buildings in İzmir to bring out their heating energy and $\mathrm{CO}_{2}$ performance for all professionals in construction and energy sector as well as for researchers in relevant disciplines. The aim is to offer certain significant values of architectural indicators. By being aware of these numerical values, it is thought that professionals would take early-precautions against high energy consumptions in the early design stage; and they might increase the performance level by applying minor architectural modifications. These values would assist to predict the level of energy performance in the early design phase.
According to findings, the majority of the buildings were in energy Class $\mathrm{B}$ and $\mathrm{C}$; and in $\mathrm{CO}_{2}$ Class $\mathrm{G}$. The former is considered to be favorable, since this situation is appropriate according to the circumstances that required by the Turkish energy performance legislation. However, the latter was a result which depicts that low performance due to the fuel type caused environment pollution extensively. It is proposed that heating systems used in residential buildings should be modernized, central heating systems should become prevalent and fuel types should be changed.

One noteworthy finding here was that none of these buildings used renewable energy resources and had maximum energy performance, i.e. in Energy Class A. This is in accordance with the breakdown of energy use in buildings in Turkey [7,8], which depicts that $80 \%$ of energy consumption was caused by conventional fuel types such as coal, lignite, oil, electricity etc. However, the use of renewable energy sources should be encouraged. This finding also reminds us a question whether the use of such energy sources might upgrade these buildings' energy class from Class B to Class A or not.

Sources [25-36] cite such related studies based on architectural issues to be taken as indicators when constructing energy strategies for new buildings and renovating existing buildings. However, this study analyzed most prevailing ones and emphasis was being on significant values of architectural considerations through certain area-based ratios. The levels of these ratios were matched with the levels of energy consumption. In other words, this study sought to classify such threshold values to indicate the relationship between the level of configuration indicators and the energy performance of residential buildings. Specifically, among those proposed threshold values of significant indicators, $A / V$ and orientation might indicate levels of energy performance directly. Although architectural considerations, in general, were mentioned in new legislations, addition of such proposed values would provide concrete recommendations for designers. This study might even be a starting point to construct a practical design guide for architects. Now, such findings are valid for the residential buildings, in İzmir, that were the subject of this study. Further investigations including larger set of sample buildings may be carried out to be comprehensive and to make generalizations throughout the country.

In detail, the results were compared with similar studies. Although residential buildings in Greece have similar building typology and located in similar climate, a study about their 
heating energy consumption, indicated that mean real heating energy consumption was $101.03 \mathrm{kWh} / \mathrm{m}^{2}$, simulated result was $112.78 \mathrm{kWh} / \mathrm{m}^{2}$ [11]. On the other hand, mean calculated energy consumption for insulated residential buildings in İzmir was $124.30 \mathrm{kWh} / \mathrm{m}^{2}$, and $164 \mathrm{kWh} / \mathrm{m}^{2}$ for all buildings. These values varied between 100 and $240 \mathrm{kWh} / \mathrm{m}^{2}$. This is very close to the values mentioned in the statistics about existing residential buildings in Turkey [9], however, these consumption values are two times higher than the ones in European countries [9,10]. It was realized that most of the residential buildings (almost 82.5\%) in Turkey like in Greece are uninsulated [11,16,39]. However residential buildings in İzmir consume more energy for heating than buildings in Greece. The reasons of this differentiation may be the usage of autonomous heating system with coal in Turkey, different $U$-values for materials and user factor. For instance, in Greece for the similar climatic zone like İzmir, maximum allowed $U$-value for walls is $0.6 \mathrm{~W} / \mathrm{m}^{2} \mathrm{~K}$ [11], however, in Turkey this value for İzmir is $0.8 \mathrm{~W} / \mathrm{m}^{2} \mathrm{~K}$ [13]. These remind us to consider that precautions and related regulations should be revised immediately to catch the European values and to fully satisfy the requirements for the latest European Energy Performance of Buildings Directive 2010/31/EC.

As regards, the best energy performed-buildings were attached/intermediate which are located in north/south and east/west direction. As a logical consequence, an existing residential building whose external surface area to net usable floor area is below 0.55 , ratio of window area to external surface area is between 0.37 and 0.6 and ratio of external wall area to net-usable area is below 0.60 , and which has an attached/intermediate zoning status, central heating system and insulation might resemble a high performance building as regard to energy efficiency. According to the model, $47 \%\left(R^{2}=0.47\right)$ of the variability in the energy consumption is accounted for by the architectural indicators. This finding enhanced the impact rate of building characteristics, which was $42 \%$ in a previous study [25]. Thus, interactions between variables and their total effect on the heating energy performance are not negligible as the mechanical variables' effect.

It is necessary to conduct such studies to guide professionals who would seek early classifications of buildings according to their energy consumption. Levels of architectural indicators would provide such information before the architectural design ends. This less-time-consuming and easy guide would provide them opportunity to make preparation before the detailed energy analyses and take early measurements. Better architectural solutions may lead to high-performed-buildings whose construction and management facilities were comparatively less costly than previous solutions.

Implementing energy legislations in regard to the European Directive may deserve a certain time, as it needs experience and constant standards. Until now, regulations were based on mainly heating loads and prepared according to European Standards. However, to determine the energy performance of residential buildings is a multi-variable and complex task, involving architectural, mechanical, constructional, economic, legal and climatic issues. In relation to above issues, legislation in Turkey requires information about the evaluation of heating energy performance of existing buildings which will be renovated, not only new buildings. This study was a preparation for this task. Further detailed investigations are fundamentals to realize the deficiencies in existing knowledge and to obtain prevailing technical and sociological information to finalize such energy policies.

\section{Acknowledgement}

The Scientific and Technological Research Council of Turkey (TÜBITAK) funded this research project (Research No: 109M450) and their contribution is gratefully acknowledged.

\section{References}

[1] M. Santamouris, Introduction on the energy rating of buildings, in: $M$ Santamouris (Ed.), Energy Performance of Residential Buildings, James \& James/Earthscan, UK, 2005, pp. 1-15.

[2] J. Smeds, M. Wall, Enhanced energy conservation in houses through high performance design, Energy and Buildings 39 (2007) 273-278.

[3] I. Borden, A. Leaman, M. Atkins, Energy Efficient Design, A Guide to Energy Efficiency and Solar Applications in Building Design, United Nations, New York, 1991.

[4] T. Keskin, H. Ünlü, Energy efficiency in Turkey and the role of local governments, in: A Research Report in Turkish Context, Heinrich Böll Stiftung Turkey Agency, Ecology, 2010, Available online at: http://www.e-efficiency.org/ tl_files/docs/HBSD-EVraporu.pdf (20.01.12).

[5] J.L. Miguez, J. Porteiro, L.M. Lopez-Gonzalez, J.E. Vicuna, S. Murillo, J.C. Moran, E. Granada, Review of the energy rating of dwellings in the European Union as a mechanism for sustainable energy, Renewable and Sustainable Energy Reviews 10 (2006) 24-45

[6] European Union, Directive 2010/31/EC of the European Parliament and of the Council of May 19th, 2010 on the Energy Performance of Buildings, Official Journal of the European Communities (2010).

[7] T. Yakar, Promoting Energy Efficiency in Buildings in Turkey, UNDP Research Project, 2011-2015, 2011, Available online at: http://ecahousingforum.eu/ wp-content/uploads/2011/08/Energy-Efficiency-in-Buildings-The-Case-ofTurkey-by-Tolgar-Yakar.pdf (05.09.12).

[8] The Ministry of Environment and Urbanization, National Climate Change Action Plan 2011-2023, General Directorate of Environmental Management, Climate Change Department, Policy and Strategy Development Division, Ankara, 2011.

[9] Ş. Dilmaç, M. Tırıs, Energy efficiency in residential Buildings in Turkey, in Turkish context. Available online at: http://www.mmo.org.tr/resimler/dosya_ ekler/d616dd38211ebb5_ek.pdf? dergi=160 (05.09.12).

[10] M. Altas, H. Fikret, E. Celebi, Energy Statistics, in Turkish context, in: Turkish 6th Energy Congress, 17-22 October, İzmir, 1994.

[11] I. Theodoridou, A.M. Papadopouos, M. Hegger, A typological classification of the Greek residential building stock, Energy and Buildings 43 (2011) 27792787

[12] Turkish Standard Institution, Turkish Regulations, TS825-The Thermal Insulation Requirements for Buildings in Turkish Context, Ankara, 1999.

[13] Ministry of Public Works, Turkish Regulations, Heat Insulation Regulation in Turkish context, Ankara, 2008.

[14] Ministry of Public Works, Turkish Regulations, Energy Efficiency Law in Turkish context, Ankara, 2007.

[15] Ministry of Public Works, Turkish Regulations, Building Energy Performance Regulation in Turkish Context, Ankara, 2008.

[16] I. Theodoridou, A.M. Papadopouos, M. Hegger, Statistical analysis of the Greek residential building stock, Energy and Buildings 43 (2011) 2422-2428.

[17] T. Papakostas, T. Papadopoulos, G. Vlahakıs, Optimisation of thermal protection in residential buildings using the variable base degree-days method, International Journal of Sustainable Energy 24 (2005) 19-31.

[18] M. Santamouris, G. Mihalakakou, P. Patargias, N. Gaitani, K. Sfakianaki, M. Papaglastra, et al., Using intelligent clustering techniques to classify the energy performance of school buildings, Energy and Buildings 39 (2007) 4551.

[19] F. Flourentzou, J.L. Genre, C.A. Roulet, T. Stöckli, EPIQR-TOBUS: a new generation of refurbishment decision aid method, Internationale Zeitschrift für Bauinstandsetzen und Baudenkmalpflege 5 (2000) 543-544

[20] C.A. Balaras, K. Droutsa, A.A. Argiriou, D.N. Asimakopoulos, EPIQR surveys of apartment buildings in Europe, Energy and Buildings 31 (2000) 111 128.

[21] B. Poel, G. Cruchten, C. Balaras, Energy performance assessment of existing dwellings, Energy and Buildings 39 (2007) 393-403.

[22] S. Alvarez, A. Blanco, J.A. Sanz, F.J. Sanchez, The Euroclass method-description of the software, in: M. Santamouris (Ed.), Energy Performance of Residential Buildings, James \& James/Earthscan, UK, 2005, pp. 71-78.

[23] Building Research Establishment of U.K, SAP2005-The Government's Standard Assessment Procedure for Energy Rating of Dwellings, Revision 1, Version 9.81, Garston, Watford, 2008.

[24] L. Pedersen, Use of different methodologies for thermal load and energy estimations in buildings including meteorological and sociological input parameters, Renewable and Sustainable Energy Reviews 11 (2007) 998-1007.

[25] O.G. Santin, L. Itard, H. Vissher, The effect of occupancy and building characteristics on energy use for space and water heating in Dutch residential building stock, Energy and Buildings 41 (2009) 1223-1232.

[26] G.A. Floridesa, S.A. Tassoub, S.A. Kalogiroua, L.C. Wrobelb, Measures used to lower building energy consumption and their cost effectiveness, Applied Energy 73 (2002) 299-328.

[27] A.S. Dili, M.A. Naseer, T.Z. Varghese, Passive environment control system of Kerala vernacular residential architecture for a comfortable indoor environment: a qualitative and quantitative analyses, Energy and Buildings 42 (2010) 917-927.

[28] M. Persson, A. Roos, M. Wall, Influence of window size on the energy balance of low energy houses, Energy and Buildings 38 (2006) 181-188.

[29] M. Wall, Energy-efficient terrace houses in Sweden simulations and measurements, Energy and Buildings 38 (2006) 627-634.

[30] K.A. Al-Sallal, Sizing windows to achieve passive cooling, passive heating, and daylighting in hot arid regions, Renewable Energy 14 (1998) 365-371. 
[31] M.Y. Numan, F.A. Almaziad, W.A. Al-Khaja, Architectural and urban design potentials for residential building energy saving in the Gulf region, Applied Energy 64 (1999) 401-410.

[32] Z. Yilmaz, Evaluation of energy efficient design strategies for different climatic zones: comparison of thermal performance of buildings in temperate-humid and hot-dry climate, Energy and Buildings 39 (2007) 306-316.

[33] G.K. Oral, A.K. Yener, N.T. Bayazit, Building envelope design with the objective to ensure thermal, visual and acoustic comfort conditions, Building and Environment 39 (2004) 281-287.

[34] R. Ünver, N.Y. Akdag, G.Z. Gedik, L.D. Öztürk, Z. Karabiber, Prediction of building envelope performance in the design stage: an application for office buildings, Building and Environment 39 (2004) 143-152.

[35] G.K. Oral, Z. Yılmaz, The limit U values for building envelope related to building form in temperate and cold climatic zones, Building and Environment 37 (2002) $1173-1180$.

[36] G. Manioğlu, Z. Yılmaz, Energy efficient design strategies in the hot dry area of Turkey, Building and Environment 43 (2008) 1301-1309.

[37] Adnan Menderes Meteorological Station.

[38] Turkish Statistical Institute, Building Construction Statistics, 2010.

[39] EN ISO 13790, Energy performance of buildings, Calculation of Energy Use for Space Heating and Cooling, European Committee for Standardization, 2008.

[40] EN 13465, Ventilation for Buildings-Calculation Methods for the Determination of Air Flow Rates in Dwellings, 2004.
[41] R.B. McCall, Fundamental Statistics for Behavioral Sciences, Harcourt Brace Jovanovich, USA, 1990.

[42] A.P. Meloa, D. Cóstolab, R. Lambertsa, J.L.M. Hensen, Assessing the accuracy of a simplified building energy simulation model using BESTEST: The case study of Brazilian regulation, Energy and Buildings 45 (2012) 219-228.

[43] R.H. Henninger, M.J. Witte, EnergyPlus Testing with Building Thermal Envelope and Fabric Load Tests from ANSI/ASHRAE Standard 140-2011, U.S. Department of Energy, Energy Efficiency and Renewable Energy Office of Building Technologies, Washington, D.C., 2012. Available online at: http://apps1.eere. energy.gov/buildings/energyplus/pdfs/energyplus_ashrae_140_envelope.pdf (20.01.2013).

[44] prEN ISO 10211, Thermal Bridges in Building Construction - Heat Flows and Surface Temperatures - Detailed Calculations, 2007.

[45] prEN 15316-3-1, heating systems in buildings-method for calculation of energy requirements and system efficiencies. Part 3-1: domestic hot water systems, characterisation of needs (Tapping Requirements), 2007.

[46] prEN 15316-3-2, Heating systems in buildings-method for calculation of system energy requirements and system efficiencies. Part 3-2: domestic hot water systems, distribution, 2007.

[47] I. Sartori, A.G. Hestnes, Energy use in the life cycle of conventional and lowenergy buildings: a review article, Energy and Buildings 39 (2007) 249-257.

[48] I. Ballarini, V. Corrado, Application of energy rating methods to the existing building stock: analysis of some residential buildings in Turin, Energy and Buildings 41 (2009) 790-800. 